\title{
Prevalence of Zoonotic Species of Campylobacter in Broiler Chicken and Humans in Assiut Governorate, Egypt
}

\author{
Mostafa FN Abushahba ${ }^{1,2 *}$, Sylvia 0 Ahmed $^{1}$, Awad A Ibrahim ${ }^{3}$ and Hanan A Mosa ${ }^{1}$ \\ ${ }^{1}$ Department of Animal Hygiene, Egypt \\ ${ }^{2}$ Department of Veterinary Pathobiology, USA \\ ${ }^{3}$ Department of Poultry Diseases, Egypt
}

*Corresponding author: Mostafa F N Abushahba, Department of Veterinary Pathobiology, College of Veterinary Medicine, Missouri 65211-5130, USA

Submission: 眥 April 12, 2018; Published: 眥 April 30, 2018

\begin{abstract}
The lack of a national campylobacteriosis surveillance system in Egypt warrants the need for periodical disease evaluation. This study aimed to determine campylobacteriosis prevalence in broiler chicken farms and slaughterhouses as well as in humans at Assiut Governorate, Egypt. Biochemical and molecular reactions have been employed to determine Campylobacterioiss prevalence. Additionally, the predisposing factors for human campylobacteriosis were assessed. The overall prevalence of Campylobacter species detected by biochemical reactions and multiplex PCR assay was found to be $23.51 \%$ and $22.46 \%$, respectively. Prevalence rates of $16.83 \%, 24 \%$ and $27.55 \%$ were recorded for the incorporated samples from broiler farms, slaughterhouses and humans, respectively. None of the analyzed demographic determinants (age, gender and residence) significantly affected Campylobacteriois prevalence in humans. Interestingly, mixed infection was the predominate finding among positive samples and none was confirmed to have C. jejuni alone. Additionally, Arcobacter was recovered either independently or coexisted with Campylobacter in poultry samples; nevertheless, zero detected from humans. This study confirms that broilers could represent an important public health threat to Assiut Governorate residents. Accordingly, measures on how to minimize the contamination level at farms, slaughterhouses and during culinary practices should be disseminated to farm workers, slaughterhouse men and consumers.
\end{abstract}

Keywords: Campylobacteriosis; Multiplex PCR; Zoonosis; Poultry; Egypt

\section{Introduction}

Among the zoonotic Campylobacter species, e.g. C. jejuni, C. coli, C. lari and $C$. upsaliensis, the former two species are responsible for the vast majority of the human food borne infections, accounting for $90 \%$ and $5-10 \%$ of cases [1], respectively. Generally, Campylobacter is the most common bacterium inducing gastroenteritis in human beings globally and can be resulting in a fatal consequence in very young children, geriatric populations and immune compromised patients [2]. Being harbor Campylobacter in their intestinal flora, poultry and subsequently their products are considered a common and main source of the bacterium to human [3]. This mainly occurs as a result of extensive contamination of broiler carcasses and different organs with the gut contents following mechanical evisceration of birds [4]. Despite the public health burden associated with campylobacteriosis and the well-known role of poultry in its transmission cycle, the disease trend is still difficult to be accurately estimated in developing countries given the lack of a national surveillance system for many zoonotic diseases [5]. The situation is aggravated with the presence of funding constraints in such countries, hence, targeted epidemiological studies could be the only resort to fill the gap. Therefore, this study was undertaken to reevaluate the prevalence of $C$. jejuni and $C$. coli in poultry in farms and slaughterhouses at Assiut Governorate, Egypt. Also, the prevalence and risk factors associated with campylobacteriosis caused by the two species of interest in patients attending Assiut University Hospital were studied.

\section{Materials and Methods}

\section{Samples}

A total of 285 samples, including 205 poultry samples and 80 human samples were recruited to this study. The two hundred and five poultry samples were collected from four poultry farms (101 cloacal swabs) and two poultry slaughterhouses (104; 26 each for intestinal swab, liver, neck and wing) located at Assiut Governorate, Egypt. However, human samples included 60 children and 20 adults 
were collected from patients attending Assiut University Hospital. The age, gender, residence and clinical summary of the sampled humans were included and analyzed.

\section{Isolation and biochemical identification of Campylobacter}

Samples were enriched in Bolton selective enrichment broth (Oxoid) for 24 hours at $10 \% \mathrm{Co}_{2}$ under $42{ }^{\circ} \mathrm{C}$ and were then cultured on modified Campylobacter selective agar base Cefoperazone Charcoal Desoxycholate Agar, mCCDA (Oxoid) at $42{ }^{\circ} \mathrm{C}$ for 48 $\mathrm{hr}$ under microaerophilic conditions. Typical colonies were biochemically identified utilizing catalase, oxidase, Gram's stain, hippurate test, sensitivity to nalidixic acid and cephalothin [3].

\section{Molecular confirmation of Campylobacter isolates}

DNA was extracted from overnight cultures of Campylobacter using Patho Gene-spin DNA/RNA Extraction Kit (Rx Biosciences, USA). Three pairs of specific primers were chosen [6] and purchased from metabion international AG, Germany. They were selected for amplification of a $650 \mathrm{bp}$ of Campylobacter 23s rRNA gene (F: tataccggtaaggagtgctggag and R: atcaattaaccttcgagcaccg), a 323bp of C.jejuni hipo gene (F: acttctttattgcttgctgc and R: gccacaacaagtaaagaagc) and a 126bp of C.coli glyA gene (F: Results gtaaaaccaaagcttatcgtg and R: tccagcaatgtgtgcaatg). The assay was performed using Qiagen Multiplex PRR Kit in Veriti Thermal Cycler (applied Biosystems) and cycling conditions were applied as recently published [7]. Gel electrophoresis was conducted for 1 hour at 100 volt and products were visualized by UV transilluminator and photographed by the gel documentation system (Biometra, Göttingen, Germany).

\section{Statistical analysis}

Statistical differences were determined using Fisher's exact test and odds ratio in the Graphpad prism 5 (Graph Pad Software, Inc., La Jolla, CA, USA). P value $\leq 0.05$ was considered significant.

\section{Ethical statement}

Informed written consent was obtained from each adult participant and parental consent was attained prior to the participation of children in this study. All participants were informed that the obtained information will be strictly confidential. Animal blood samples were collected following agreement of the owners and animals were handled according to the Assiut University regulatory rules for animal research. The animal and human work were approved by the ethics committee of Assiut University, Egypt.

Table 1: Identification of Campylobacter spp. by biochemical \& molecular techniques

\begin{tabular}{|c|c|c|c|c|c|c|c|c|c|}
\hline $\begin{array}{c}\text { Source \& } \\
\text { type of sample }\end{array}$ & & $\begin{array}{c}\text { No. } \\
\text { Examined }\end{array}$ & $\begin{array}{c}\text { Biochemical } \\
\text { Tests }\end{array}$ & & & $\begin{array}{c}\text { Multiplex PCR } \\
\text { Assay }\end{array}$ & & & \\
\hline & & & $\begin{array}{c}\text { Campylobacter } \\
\text { species }\end{array}$ & C. jejuni & C. coli & $\begin{array}{c}\text { Campylobacter } \\
\text { species }\end{array}$ & C. jejuni & C. coli & $\begin{array}{c}\text { Mixed } \\
\text { Infection }\end{array}$ \\
\hline & & & $\begin{array}{l}\text { Positive } \\
\text { No. (\%) }\end{array}$ & $\begin{array}{l}\text { Positive } \\
\text { No. (\%) }\end{array}$ & $\begin{array}{l}\text { Positive } \\
\text { No. (\%) }\end{array}$ & $\begin{array}{l}\text { Positive } \\
\text { No. (\%) }\end{array}$ & $\begin{array}{l}\text { Positive } \\
\text { No. (\%) }\end{array}$ & $\begin{array}{l}\text { Positive } \\
\text { No. (\%) }\end{array}$ & $\begin{array}{l}\text { Positive } \\
\text { No. (\%) }\end{array}$ \\
\hline Poultry farms & Cloacal swab & 101 & $20(19.80 \%)$ & $11(10.89)$ & $9(8.91)$ & 17 (16.83) & 0 & $4(3.96)$ & $\begin{array}{c}13 \\
(12.87)\end{array}$ \\
\hline \multirow[t]{4}{*}{$\begin{array}{c}\text { Poultry } \\
\text { slaughterhouses }\end{array}$} & $\begin{array}{c}\text { Intestinal } \\
\text { swab }\end{array}$ & 26 & 5 (19.23) & $4(15.38)$ & $1(3.85)$ & $5(19.23)$ & 0 & 0 & 5 (19.23) \\
\hline & Liver & 26 & 5 (19.23) & $3(11.54)$ & $2(7.69)$ & $5(19.23)$ & 0 & 0 & $5(19.23)$ \\
\hline & Neck & 26 & $7(26.92)$ & $3(11.54)$ & $4(15.38)$ & 7 (26.92) & 0 & $2(7.69)$ & 5 (19.23) \\
\hline & Wing & 26 & 8 (30.77) & $4(15.38)$ & $4(15.38)$ & $8(30.77)$ & 0 & $2(7.69)$ & $6(23.08)$ \\
\hline $\begin{array}{c}\text { Assiut Uni. } \\
\text { Hospital }\end{array}$ & Human stool & 80 & $22(27.5)$ & $16(20)$ & $6(7.5)$ & $22(27.5)$ & 0 & $4(5)$ & $18(22.5)$ \\
\hline Total & & 285 & 67 (23.51) & 41 (14.39) & $26(9.12)$ & $64(22.46)$ & 0 & $12(4.21)$ & $\begin{array}{c}52 \\
(18.25)\end{array}$ \\
\hline
\end{tabular}

The overall prevalence of Campylobacter species detected by biochemical reactions was found to be $23.51 \%$ (67 of 285). Only three isolates were found to be negative by multiplex assay. None of the confirmed isolates were found to be $C$. jejuni; nevertheless, $C$. coli was confirmed in 12 isolates and the rest of isolates were matching a mixed infection of $C$. jejuni and C. coli (Table 1). Arcobacter prevalence in farms and slaughterhouses was also reported in this study. Arcobacter alone or combined with Campylobacter was found in $30.24 \%$ and $6.83 \%$, respectively, out of 205 examined poultry samples. Unlike poultry, we failed to isolate Arcobacter from the examined human samples (Table S1). 
Table S1: Co-existence of Arcobacter and Campylobacter in poultry samples

\begin{tabular}{|c|c|c|c|c|c|}
\hline \multirow[t]{2}{*}{ Source of Sample } & \multirow[t]{2}{*}{ No. Examined } & \multicolumn{2}{|c|}{ Arcobacter Only } & \multicolumn{2}{|c|}{ Campylobacter + Arcobacter } \\
\hline & & No. (\%) & Odds ratio $(95 \% \mathrm{CI})$ & No. (\%) & Odds ratio $(95 \% \mathrm{CI})$ \\
\hline \multicolumn{6}{|l|}{ Farms } \\
\hline A & 23 & 12 & 11.45 (2.166 to 60.58$)$ & $4(17.39)$ & $1.47(0.3276$ to 6.629$)$ \\
\hline B & 23 & 2 & Ref. & $0(0)$ & $\begin{array}{c}0.134(0.006892 \text { to } \\
2.635)\end{array}$ \\
\hline $\mathrm{C}$ & 23 & $10(43.48)$ & 8.07 (1.522 to 42.85 ) & $0(0)$ & $\begin{array}{c}0.134(0.006892 \text { to } \\
2.635)\end{array}$ \\
\hline $\mathrm{D}$ & 32 & 28 & 73.50 (12.28 to 440.1$)$ & $4(12.5)$ & Ref. \\
\hline Total & 101 & $52(51.48)$ & $\mathrm{P}<0.0001$ & 8 & $P=0.0525$ \\
\hline \multicolumn{6}{|l|}{$\begin{array}{c}\text { Slaughter } \\
\text { houses }\end{array}$} \\
\hline A & 52 & 2 & $\begin{array}{c}0.22(0.04433 \text { to } \\
1.092)\end{array}$ & $0(0)$ & $\begin{array}{c}0.06813(0.003733 \text { to } \\
1.243)\end{array}$ \\
\hline B & 52 & 8 & 4.54 (0.9159 to 22.56$)$ & $6(11.54)$ & $\begin{array}{c}14.68(0.8043 \text { to } \\
267.8)\end{array}$ \\
\hline Total & 104 & $10(9.62)$ & $\mathrm{P}=0.0923$ & 6 & $P=0.0268$ \\
\hline Overall total & 205 & $62(30.24)$ & - & $14(6.83)$ & - \\
\hline
\end{tabular}

\begin{tabular}{|c|c|c|}
\hline Fisher's exact test & Arcobacter only & Campylobacter + Arcobacter \\
\hline & Odds ratio $\mathbf{( 9 5 \%} \mathbf{C I})$ & Odds ratio (95\% CI) \\
\hline Farms & $9.98(4.665$ to 21.33$)$ & $1.40(0.4695$ to 4.205$)$ \\
\hline Slaughterhouses & $0.10(0.04688$ to 0.2143$)$ & $0.71(0.2378$ to 2.130$)$ \\
\hline P value & $<0.0001$ & 0.59 \\
\hline
\end{tabular}

Table 2: Distribution of Campylobacter species in different poultry farms and slaughterhouses

\begin{tabular}{|c|c|c|c|c|c|c|}
\hline $\begin{array}{c}\text { Source \& type of } \\
\text { samples }\end{array}$ & & No. examined & $\begin{array}{l}\text { Campylobacter } \\
\text { species }\end{array}$ & & C.coli & Mixed Infection \\
\hline & & & No. (\%) & $\begin{array}{c}\text { Odds ratio } \\
(95 \%, \mathrm{CI})\end{array}$ & No. (\%) & No. (\%) \\
\hline \multicolumn{7}{|l|}{ Farms } \\
\hline A & Cloacal swab & 23 & $6(26.09)$ & $7.76(0.85-70.79)$ & $1(4.34)$ & $5(21.74)$ \\
\hline B & & 23 & $6(26.09)$ & $7.76(0.85-70.79)$ & $2(8.69)$ & $4(17.39)$ \\
\hline $\mathrm{C}$ & & 23 & $1(4.34)$ & Ref. & $1(4.34)$ & $0(0.00)$ \\
\hline $\mathrm{D}$ & & 32 & 4 (12.) & $3.14(0.33-30.18)$ & $0(0.00)$ & $4(12.5)$ \\
\hline Total & & 101 & 17 (16.83) & & $4(3.96)$ & $13(12.87)$ \\
\hline \multicolumn{7}{|l|}{ Slaughterhouses } \\
\hline & Intestinal swab & 13 & $2(15.38)$ & Ref. & $0(0.00)$ & $2(15.38)$ \\
\hline \multirow[t]{5}{*}{ A } & Liver & 13 & $3(23.07)$ & $\begin{array}{c}1.650(0.2269 \text { to } \\
12.00)\end{array}$ & $0(0.00)$ & $3(23.07)$ \\
\hline & Neck & 13 & $4(30.77)$ & $\begin{array}{c}2.44(0.3609 \text { to } \\
16.55)\end{array}$ & $1(7.69)$ & $3(23.07)$ \\
\hline & Wing & 13 & $2(15.38)$ & $\begin{array}{c}1.000(0.1187 \text { to } \\
8.425)\end{array}$ & $1(7.69)$ & $1(7.69)$ \\
\hline & Total & 52 & $11(21.15)$ & $\begin{array}{c}0.7282(0.2946 \text { to } \\
1.800)\end{array}$ & $2(3.84)$ & $9(17.30)$ \\
\hline & Intestinal swab & 13 & $3(23.08)$ & $\begin{array}{c}1.650(0.2269 \text { to } \\
12.00)\end{array}$ & $0(0.00)$ & $3(23.08)$ \\
\hline B & Liver & 13 & $2(15.38)$ & Ref. & $0(0.00)$ & $2(15.38)$ \\
\hline
\end{tabular}




\begin{tabular}{|c|c|c|c|c|c|c|}
\hline & Neck & 13 & $3(23.08)$ & $\begin{array}{c}1.650(0.2269 \text { to } \\
12.00)\end{array}$ & $1(7.69)$ & $2(15.38)$ \\
\hline & Wing & 13 & $6(46.15)$ & $\begin{array}{c}4.714(0.7337 \text { to } \\
30.29)\end{array}$ & $1(7.69)$ & $5(38.46)$ \\
\hline & Total & 52 & $14(26.92)$ & $\begin{array}{c}1.373(0.5556 \text { to } \\
3.394)\end{array}$ & $2(3.84)$ & $12(23.07)$ \\
\hline Overall Total & & 104 & $25(24)$ & - & $4(3.84)$ & $21(20.19)$ \\
\hline
\end{tabular}

Table 3: Simultaneous detection of Campylobacter species in different examined parts of positive chicken carcasses (n=15) a: Mixed infection, b: C.coli

\begin{tabular}{|c|c|c|c|c|c|c|c|}
\hline \multirow[t]{2}{*}{ Carcass } & \multirow{2}{*}{$\begin{array}{c}\text { No of } \\
\text { Campylobacter } \\
\text { spp Isolates } \\
\end{array}$} & \multicolumn{2}{|c|}{ Type of Isolates } & \multicolumn{4}{|c|}{ Origin of Isolates } \\
\hline & & C.coli & $\begin{array}{c}\text { Mixed } \\
\text { infection }\end{array}$ & Intestine & Liver & Neck & Wing \\
\hline 1 & 1 & - & 1 & - & - & a & - \\
\hline 2 & 1 & - & 1 & - & - & - & $\mathrm{a}$ \\
\hline 3 & 1 & - & 1 & - & a & - & - \\
\hline 4 & 4 & 1 & 3 & a & a & a & $\mathrm{b}$ \\
\hline 5 & 2 & - & 2 & $\mathrm{a}$ & $\mathrm{a}$ & - & - \\
\hline 6 & 1 & - & 1 & - & - & $\mathrm{a}$ & - \\
\hline 7 & 1 & 1 & - & - & - & $\mathrm{b}$ & - \\
\hline 8 & 2 & 1 & 1 & - & - & $\mathrm{a}$ & $\mathrm{b}$ \\
\hline 9 & 2 & 1 & 1 & - & - & $\mathrm{b}$ & a \\
\hline 10 & 2 & - & 2 & - & - & $\mathrm{a}$ & a \\
\hline 11 & 1 & - & 1 & - & $\mathrm{a}$ & - & - \\
\hline 12 & 2 & - & 2 & $\mathrm{a}$ & $\mathrm{a}$ & - & - \\
\hline 13 & 1 & - & 1 & - & - & - & a \\
\hline 14 & 2 & - & 2 & $\mathrm{a}$ & - & - & $\mathrm{a}$ \\
\hline 15 & 2 & - & 2 & $\mathrm{a}$ & - & - & a \\
\hline Total & 25 & 4 & 21 & 5 & 5 & 7 & 8 \\
\hline
\end{tabular}

The prevalence rates of Campylobacter spp. in sampled chicken from farms and slaughterhouses were $16.83 \%$ and $24 \%$, respectively. Farm A similar to farm B had the highest prevalence rate and slaughterhouse $B$ had a slightly higher prevalence than slaughterhouse A (Table 2). All sampled chicken carcasses, but no. 7 had a mixed infection at least in one organ. However, neither the intestinal swabs nor livers sampled from slaughterhouses had C. coli contamination. Additionally, two wings and two livers were found to have the species of interest (Table 3).
(Table 4) revealed that the prevalence of Campylobacter infection was higher in adults $(30 \%)$ than children $(26.66 \%)$ and none of the analyzed variables had significant impact on getting campylobacteriosis in humans. As illustrated in Table S2, fever was documented in $87.5 \%$ of infected children, however, all had diarrhea and abdominal pain. Additionally, blood was seen in $25 \%$ of stool samples of infected children and surprisingly, our study reported the presence of an un expectedly high percentage (87.5\%) of infected children manifesting emesis.

Table 4: Prevalence and risk factors of Campylobacter infection in humans

\begin{tabular}{|c|c|c|c|c|c|}
\hline Variable & No. examined & \multicolumn{2}{|c|}{ Campylobacter species } & C. coli & Mixed infection \\
\hline Children & & No. (\%) & Odds ratio (95\% CI) & No. (\%) & No. (\%) \\
\hline Age (Year) & & & & & \\
\hline$\leq 1$ & 33 & $10(30.3)$ & $\begin{array}{c}1.478(0.4263 \text { to } \\
5.126)\end{array}$ & $2(6.06)$ & $8(24.24)$ \\
\hline $1.1-2$ & 22 & $5(22.72)$ & Ref. & $2(9.09)$ & $3(13.64)$ \\
\hline$>2$ & 4 & $1(25)$ & $\begin{array}{c}1.133(0.09551 \text { to } \\
13.45)\end{array}$ & $0(0.00)$ & $1(25)$ \\
\hline
\end{tabular}




\begin{tabular}{|c|c|c|c|c|c|}
\hline Gender & & & & & \\
\hline Male & 33 & $10(30.30)$ & $\begin{array}{c}1.522(0.4711 \text { to } \\
4.916)\end{array}$ & $1(3.03)$ & 9 (27.27) \\
\hline Female & 27 & $6(22.22)$ & $\begin{array}{c}0.6571(0.2034 \text { to } \\
2.123)\end{array}$ & $3(11.11)$ & $3(11.11)$ \\
\hline \multicolumn{6}{|l|}{ District } \\
\hline Manfalut & 20 & $2(10)$ & Ref. & $0(0.00)$ & $2(10)$ \\
\hline Dayrut & 8 & $2(25)$ & $3(0.3434$ to 26.21$)$ & $1(12.5)$ & $1(12.5)$ \\
\hline Abnub & 8 & $5(62.5)$ & 15 (1.939 to 116$)$ & $1(12.5)$ & $4(50)$ \\
\hline Sodfa & 7 & $2(28.57)$ & $3.6(0.4002$ to 32.38$)$ & $0(0.00)$ & 2 (28.57) \\
\hline El Badari & 6 & $2(33.33)$ & 4.5 (0.4791 to 42.27$)$ & $2(33.33)$ & $0(0.00)$ \\
\hline Others & 11 & $3(27.27)$ & 3.37 (0.4688 to 24.3$)$ & $0(0.00)$ & $3(27.27)$ \\
\hline Total & 60 & $16(26.66)$ & 0.85 (0.2783 to 2.587$)$ & $4(6.66)$ & $12(20)$ \\
\hline \multicolumn{6}{|l|}{ Adults } \\
\hline \multicolumn{6}{|l|}{ Age (Year) } \\
\hline $18-39$ & 14 & $6(42.86)$ & $\begin{array}{c}9.941(0.4693 \text { to } \\
210.6)\end{array}$ & $0(0.00)$ & $6(42.86)$ \\
\hline$\geq 40$ & 6 & $0(0.00)$ & $\begin{array}{c}0.1006(0.004749 \text { to } \\
2.131)\end{array}$ & $0(0.00)$ & $0(0.00)$ \\
\hline \multicolumn{6}{|l|}{ Gender } \\
\hline Male & 12 & $4(33.33)$ & $\begin{array}{c}1.500(0.2028 \text { to } \\
11.09)\end{array}$ & $0(0.00)$ & $4(33.33)$ \\
\hline Female & 8 & $2(25)$ & 0.67 (0.09 to 4.93$)$ & $0(0.00)$ & $2(25)$ \\
\hline \multicolumn{6}{|l|}{ Diarrhea } \\
\hline Yes & 8 & $4(50)$ & $5(0.6397$ to 39.08$)$ & $0(0.00)$ & $4(50)$ \\
\hline No & 12 & $2(16.66)$ & $\begin{array}{c}0.20(0.02559 \text { to } \\
1.563)\end{array}$ & $0(0.00)$ & $2(16.66)$ \\
\hline Total & 20 & $6(30)$ & $\begin{array}{c}1.179(0.3866 \text { to } \\
3.593)\end{array}$ & $0(0.00)$ & $6(30)$ \\
\hline
\end{tabular}

Table S2: Clinical symptoms on the Campylobacter-positive children

\begin{tabular}{|c|c|c|}
\hline Symptom & $\begin{array}{c}\text { No. of patients (Total } \\
\text { no. 16) }\end{array}$ & \% \\
\hline Fever & 14 & 87.5 \\
\hline Vomiting & 14 & 87.5 \\
\hline Blood in stool & 4 & 25 \\
\hline Diarrhea & 16 & 100 \\
\hline Abdominal pain & 16 & 100 \\
\hline
\end{tabular}

\section{Discussion}

Being of a low price relative to red meat and fish, poultry meat is a popular protein source for all Egyptians. However, contaminated poultry and poultry products can disseminate many zoonoses to humans, primarily including campylobacteiosis, thus representing a serious public health threat [8]. This threat is underestimated in developing countries owing to the lack of a national surveillance system for a such type of foodborne zoonosis [5]. Accordingly, periodical evaluation of the foodborne campylobacteriosis has to be implemented.

The present study combined both biochemical and multiplex PCR assays for identification of Campylobacter in broiler chicken and humans in Assiut Governorate, Egypt. Multiplex PCRassay confirmed that 64 isolates of the 67 presumptively identified Campylobacter colonies were true positive. In contrary to biochemical reactions which does not typically detect mixed infection of Campylobacter, the current multiplex assay could reveal that up to $18.25 \%$ (52 of 285) were having a mixed infection of both $C$. jejuni and C. coli, the rest of the samples were found to be $C$. coli alone $(4.21 \%, 12$ of $285)$; never the less, none of them confirmed to have $C$. jejuni alone. Unlike other studies that showed the predominance of $C$. jejuni [9] or $C$. coli [10], our study stated that mixed infection was superior in all types of examined samples. Although there was an in significant difference in using either biochemical reactions or multiplex PCR assay in identifying Campylobacter species (95.52\% compatibility), but multiplex assay surpassed biochemical reactions in detecting mixed infection, indicating the importance of such advanced assay in precise Campylobacter identification. Accordingly, a combination of both assays would be an excellent match for setting an efficient and cost effective diagnostic strategy for campylobacteriosis, thus facilitating rapid monitoring of such important foodborne zoonosis.

In this study, 3 of the 41 biochemically identified $C$. jejuni were found to be negative by multiplex PCR assay. Also, 5 isolates of them were confirmed to be $C$. coli. Such false negative results produced by hippurate test could be due to the existence or even production 
of amino acids or peptides in the culture media [11]. Only 7 of 26 C. coli were confirmed by multiplex PCR while the rest was found to be a mixed infection. A reliable hippurate test result depends mainly on adjusting cell suspension turbidity which subsequently affects the color production and intensity [12]. This can be straight forward in testing reference strains, but in mixed infection the process is difficult to be controlled. For instance, upon employing the hippurate test, we have recorded a color change that was strong in some isolates and weak in others. Strong color-related isolates were suspected as $C$. jejuni from the beginning and mostly were further confirmed to be a mixed infection as noted above. However, those of weak color or colorless test results (along with the antimicrobial testing) were suspected as $C$. coli. Most of these isolates were also merged to mixed infection. The color weakness or the lack of color even with the presence of $C$. jejuni could be attributed to the variability in the $C$. jejuni concentration in the used inocula compared to other Campylobacter species or related species or the presence of amino acids or peptides as noted earlier.

The appearance of unfavorable growth at the initial Campylobacter isolation and identification steps followed in the present study was challenging. Such growth was in the form of translucent, beige to off-white, small colonies unlike the typical colonies of Campylobacter on mCCDA plates incubated at $37{ }^{\circ} \mathrm{C}$. Our first thought was that the growth might be Campylobacterrelated bacteria able to grow on the selective agar medium, mCCDA as reported elsewhere [13]. The colonies were found to be Gram negative with spiral shaped rodes, hippurate negative, grown in air at $25{ }^{\circ} \mathrm{C}$ and $37{ }^{\circ} \mathrm{C}$ and not at $42{ }^{\circ} \mathrm{C}$ that typically matches the Arcobacter spp. identification scheme [3]. Taking the advantage of the inability of Arcobacter to grow above $37^{\circ} \mathrm{C}$ unlike Campylobacter, we have completed our isolation protocol at $42{ }^{\circ} \mathrm{C}$ and this change was the possible reason behind the failure of further isolation of Arcobacter from those handled by the new protocol i.e. some samples derived from slaughterhouses and all human samples.

Despite the insignificant difference between farms, OR showed that both farms A and B had a higher Campylobacter contamination (OR for each $=7.76$ (95\% CI, 0.85-70.79) compared to other farms. Compared to our study, a higher percentage, $38.1 \%$ of Campylobacter contamination were reported by [14]. Mixed infection was the predominate finding in the examined cloacal swabs $(12.87 \%, 13$ of 101). This was nearly similar to that $(12.4 \%)$ reported in Ecuador [15]. Conversely, a higher percentage of mixed infection (22\%) was encountered by [16] and a lower percentage, $7 \%$ was detected by [17], respectively. C. coli was isolated from $3.96 \%$ of the examined cloacal swabs. Lower percentage $(1.79 \%)$ was isolated by [18] and a much higher percentage, $33.33 \%$, was detected by [19], respectively.

The variation in the Campylobacter recovery rate from different farms included in this study could be as a result of the difference in handling and management practices applied in different farms that affected the transmission pattern of Campylobacter from the environment to the broilers [20]. This study showed a low prevalence rate of Campylobacter in farms because sampling was conducted between March and May. Such sampling period falls in the months (January and May) which previously found to have the lowest cumulative incidence of Campylobacter [21].

The overall prevalence in slaughterhouses was $24 \%$ accounted for $21.19 \%$ and $26.92 \%$ for slaughterhouse A and B, respectively. No statistical difference was observed between the two studied slaughterhouses, but slaughterhouse B showed a slightly higher odds of contamination compared to slaughterhouse B. Chicken neck had the highest contamination ratio $(30.77 \%, \mathrm{OR}=2.44$ (95\% CI, 0.3609 to 16.55)) in the sampled chicken derived from slaughterhouse A, however, wing had greatest prevalence and odds of contamination in the other slaughterhouse $(46.15, \mathrm{OR}=$ 4.714 (95\% CI, 0.7337 to 30.29)). Similarly, [22] reported that wing, neck and legs had the highest rate of contamination with Campylobacter. The high isolation rate of Campylobacter in chicken wings recovered in this study could be due to imperfect scalding, post scalding contamination, or due to the combination of both [23]. Also, feathers could be played an essential role in such a high contamination following getting the bacteria during transport, plucking process or during their mechanical removal in the slaughterhouses [24].

Owing to its lower price compared to beef liver, chicken liver became a popular for many people in the Egyptian cuisine. Unfortunately, Campylobacter enteritis associated with its consumption has been reported mainly as a result of post slaughtering contamination and additionally following systemic infection of live birds [25]. Campylobacter could be isolated in a $19.23 \%$ (5 of 26) of examined samples, thus chicken liver could represent an important public health threat and measures on how to minimize contamination should be disseminated to both slaughterhouse men and consumers. A much lower percentage (4\%) was detected recently in Giza, Egypt [7] however, a higher isolation rate $(24 \%)$ was documented elsewhere [26]. Contamination level detected in this study varied from carcass to another as well as between the organs of the same carcass. Accordingly, strict hygienic measures have to be applied and awareness regarding the risk of environmental contamination should be promoted to slaughterhouse men along with postmortem examination of poultry.

On the other hand, the overall prevalence of Campylobacterioisis in humans was $27.5 \%$. This result was higher than a $8.1 \%$ [27]. The much higher percentage detected in our study could be attributed to inclusion of stool samples primarily obtained from gastroenteritis-infected individuals rather than investigating the disease in the general population. Sampled children showed a higher prevalence of Campylobacter spp. (26.66\%) compared to a previous study that showed an isolation rate accounted for $9.6 \%$ [28]. Similarly, our study had a higher prevalence of $C$. coli $(6.66 \%)$ and mixed infection (20\%) in children than those reported by [29] which accounted for $1.11 \%$ and $2.22 \%$, respectively. Such high prevalence noticed in our study may be attributed to; firstly, most of the sampled humans were originating from villages which usually does not adopt the basic hygienic standards and precautions in 
contact and handling of live poultry. Secondly, over 41\% (33 of 88) of the sampled humans were primarily risky infants of an age $\leq$ 1 year. Infants were documented to be at a higher risk of getting campylobacteriosis based on their impaired immunity, especially in developing countries [5]. Finally, sampling was achieved between May and August and those months were previously shown to have a substantial increase in the Campylobacter isolation rate in children compared to other months of the year [30].

Children are usually prone to get campylobacteriosis more likely than adults as mentioned in several reports and the bacterium is one of the most frequently isolated bacteria from stools of infants with diarrhea in developing countries [5]. For instance, it was found that children were more commonly infected with Campylobacter $(19 \%)$ than adult males (8\%) and females (7\%) [31]. Never the less, our study stated a higher prevalence in adults $(30 \%)$ than children (26.66\%). This result came in accordance with [32] who noticed that prevalence of campylobacter in adult was also higher than that in children, however, he reported much lower prevalence rate accounted for $9.5 \%$ and $3.6 \%$, respectively. Our finding is statistically insignificant and also, the odds ratio revealed that adults are at slightly higher risk $(\mathrm{OR}=1.179$ (95\% CI, 0.3866 to 3.593) of acquiring the disease compared to children. Regarding the gender of the examined children, a $30.03 \%$ and $22.22 \%$ of males and females were found to be infected with Campylobacter, respectively. The result was insignificant, but odds ratio indicated that males are more likely to contract campylobacteriosis $(\mathrm{OR}=1.522$ (95\% CI, 0.4711 to 4.916 ) than females. Similarly,[33] reported that the Campylobacter infection rate was significantly higher among males than females.

The impact of age on acquiring campylobacteriosis by children was also assessed in the present study. Among the three studied age groups, $\leq 1$ year aged children had the highest prevalence rate $(33 \%)$. A typically similar rate $(32.6 \%)$ has been previously reported in Cairo [34]. Concerning the residence of sampled children, insignificant variation between different districts was encountered, however, the OR revealed that not all districts had the same Campylobacter distribution; Abnub was the highest $(\mathrm{OR}=15$ (95\% CI, 1.939 to 116) followed by El Badari (OR= 4.5 (95\% CI, 0.4791 to 42.27 ) and Sodfa (OR= 3.6 ( $95 \%$ CI, 0.4002 to 32.38)).

This difference is difficult to be reasoned, but it can be related to eating customs and preferences and close proximity to birds as well as the incomparable number of children examined from each district. Additionally, it is worthy to mention that most of the children sampled from Abnub were primary of $\leq 1$ year that was recorded to have the highest risk of acquiring campylobacetriosis. These factors could individually or collectively contribute to alleviate such clear discrepancy between different districts. Fever was recorded in $87.5 \%$ of infected children, however, all patients had diarrhea and abdominal pain. This results were assured by [35]. The presence of blood in $25 \%$ of stool samples of infected children may be due to the delayed hospitalization of sick children. Blood in stools of Campylobacter-infected children appears within the first day of disease onset and usually lasts for three days [36]. Another reason behind this relatively lower percentage of bloody stool compared to other symptoms in patients could be the early life production of IgG antibodies against Campylobacter in developing countries [37]. Although vomiting is a less frequent sign of Campylobacteriosis and only occurs in approximately $20 \%$ of patients [38], our study showed a completely contradicting finding. Surprisingly, our study reported the presence of an unexpected percentage (87.5\%) of infected children manifesting emesis.

This finding has never been reported elsewhere and needs explanation. The presence of other gastrointestinal infection [39] and the small number of infected patients $(n o=16)$ used for setting the present estimate could be possible reasons. Interestingly, the impact of gender on acquiring Campylobacter infection in adults was nearly similar to that in children participated in the present study. Campylobacter was found to infect adult males more likely (OR=1.500 (9\% CI, 0.2028 to 11.09) than adult females (OR= 0.67 ( $95 \%$ CI, 0.09 to 4.93). This difference was also found insignificant and the increased odds of exposure of males versus females could be attributed to the immune response. Under rural Egyptian setting, females get involved in practicing traditional aviculture as well as kitchen responsibilities early in their life thus they are exposed to Campylobacter repeatedly than males and as a result, females may be more likely develop specific antibodies to the bacteria than males.

Campylobacterioisis prevalence appears to wane with age as reported in our study. The prevalence of Campylobacter infection was decreased from $42.86 \%$ in the age group of $18-39$ years old to $0 \%$ in $\geq 40$ years old. This result indicated that the disease is not a problem in old ages. This reinforces the impression that excessive exposure of individuals to Campylobacter over the life could result in the development of protective immunity. Similarly, [40] reported that $36.5 \%$ of all Campylobacter isolates was isolated from adults aged 20-39 years.

The prevalence of Campylobacter in diarrheic adults (50\%) was higher than that of non- diarrheic (16.66\%). Statistically, the difference between both groups was not significant, however, diarrheic individuals were found to be infected more likely with Campylobacter compared to non-diarrheic.

\section{Conclusion}

The present study reports the detection of mixed infection of Campylobacter species in different poultry farms and slaughterhouses. Co-existence of Arcobacter with Campylobacter in the examined poultry samples is a striking feature for this study. This confirms that broilers could represent an important public health threat to the people residing in Assiut Governorate. Accordingly, measures on how to minimize the contamination level at farms, slaughterhouses and during culinary practices should be disseminated to farm workers, slaughterhouse men and consumers. Furthermore, a combination of both biochemical and multiplex assays would be an excellent match for setting an efficient and cost effective diagnostic strategy for campylobacteriosis, thus facilitating rapid monitoring of such important foodborne zoonosis. 


\section{Acknowledgement}

Sincere thanks are due to Dr. Shaban Sror, Department of Pediatrics, Faculty of Medicine, Assiut University, Egypt, for helping us in collection of human samples.

\section{References}

1. Mikulić M, Humski A, Njari B, Ostović M, Duvnjak S, et al. (2016) Prevalence of thermotolerant Campylobacter spp. in chicken meat in Croatia and multilocus sequence typing of a small subset of Campylobacter jejuni and Campylobacter coli isolates. Food Technol Biotechnol 54(4): 475-481.

2. WHO (2017) Campylobacter. World Health Organization, Geneva, Switzerland.

3. Bhunia A (2008) Campylobacter and Arcobacter. In: Foodborne Microb, Pathog Mech, Pathog (Eds.), (1 $1^{\text {St }}$ edn), Springer Science ,New York, USA. pp. 217-26.

4. Posch J, Feierl G, Wuest G, Sixl W, Schmidt S, et al.(2006) Transmission of Campylobacter spp. in a poultry slaughterhouse and genetic characterisation of the isolates by pulsed-field gel electrophoresis. $\mathrm{Br}$ Poult Sci 47(3): 286-93.

5. Coker AO, Isokpehi RD, Thomas BN, Amisu KO, Obi CL (2002) Human campylobacteriosis in developing countries. Emerg Infect Dis 8(3): 237 44

6. Wang G, Clark CG, Taylor TM, Pucknell C, Barton C, et al. (2002) Colony multiplex PCR assay for identification and differentiation of Campylobacter jejuni, C. coli, C. lari, C. upsaliensis, and C. fetus subsp. fetus. J Clin Microbiol 40(12): 4744-4747.

7. Youseef A, Ibrahim A, Sayed A, Sobhy M (2017) Occurrence of Campylobacter species in chickens by Multiplex Polymerase Chain Reaction. Assiut Vet Med J 63(152): 66-72.

8. Hafez HM, Hauck R (2015) Zoonoses with public health relevance in poultry. Zoonoses-Infections Affect. Humans Anim. Focus Public Heal Asp 103-23.

9. Anderson J, Horn BJ, Gilpin BJ (2012) The prevalence and genetic diversity of Campylobacter spp. in domestic "Backyard" poultry in Canterbury, New zealand. Zoonoses Public Health 59(1): 52-60.

10. Awadallah M, Ahmed H, El-Gedawy A, Saad AM (2014) Molecular identification of C. jejuni and C. coli in chicken and humans, at Zagazig, Egypt, with reference to the survival of $C$. jejuni in chicken meat at refrigeration and freezing temperatures. International Food Research Journal 21(5): 1801-1812.

11. Denis M, Soumet C, Rivoal K, Ermel G, Blivet D, et al. (1999) Development of a m-PCR assay for simultaneous identification of Campylobacter jejuni and C. coli. Lett Appl Microbiol 29(6): 406-10.

12. Nakari UM, Puhakka A, Siitonen A (2008) Correct identification and discrimination between Campylobacter jejuni and C. coli by a standardized hippurate test and species-specific polymerase chain reaction. Eur J Clin Microbiol Infect Dis 27(7): 513-518.

13. Corry JEL, Atabay HI (1997) Comparison of the productivity of cefoperazone amphotericin teicoplanin (CAT) agar and modified charcoal cefoperazone deoxycholate (mCCD) agar for various strains of Campylobacter, Arcobacter and Helicobacter pullorum. Int J Food Microbiol 38: 201-209.

14. Torralbo A, Borge C, Allepuz A, García-Bocanegra I, Sheppard SK, et al. (2014) Prevalence and risk factors of Campylobacter infection in broiler flocks from southern Spain. Prev Vet Med 114(2): 106-113.

15. Vinueza-Burgos C, Wautier M, Martiny D, Cisneros M, Damme I Van, et al. (2017) Prevalence, antimicrobial resistance and genetic diversity of
Campylobacter coli and Campylobacter jejuni in Ecuadorian broilers at slaughter age. Poult Sci 96(7): 2366-2374.

16. Ansari-Lari M, Hosseinzadeh S, Shekarforoush SS, Abdollahi M, Berizi E (2011) Prevalence and risk factors associated with campylobacter infections in broiler flocks in Shiraz, southern Iran. Int J Food Microbiol 144(3): 475-479.

17. Henry I, Reichardt J, Denis M, Cardinale E (2011) Prevalence and risk factors for Campylobacter spp. in chicken broiler flocks in Reunion Island (Indian Ocean). Prev Vet Med 100(1): 64-70.

18. Zweifel C, Scheu KD, Keel M, Renggli F, Stephan R (2008) Occurrence and genotypes of Campylobacter in broiler flocks, other farm animals, and the environment during several rearing periods on selected poultry farms. Int J Food Microbiol 125(2): 182-187.

19. Begum S, Sekar M, Gunaseelan L, Gawande M, Suganya G, et al. (2015) Molecular identification of Campylobacter jejuni and coli from chicken, calves and dogs to determine its potential threat on human being. Vet World 8(12): 1420-1423.

20.Van De Giessen AW, Tilburg JJ, Ritmeester WS, Van Der Plas J (1998) Reduction of campylobacter infections in broiler flocks by application of hygiene measures. Epidemiol Infect 121(1): 57-66.

21. Hansson I (2007) Bacteriological and Epidemiological Studies of Campylobacter spp. in Swedish Broilers. Swedish University of Agricultural Sciences.

22. Seliwiorstow T, Baré J, Van Damme I, Uyttendaele M, De Zutter L (2015) Campylobacter carcass contamination throughout the slaughter process of Campylobacter-positive broiler batches. Int J Food Microbiol 194: 2531.

23. Cason J a, Hinton a, Buhr RJ (2004) Impact of feathers and feather follicles on broiler carcass bacteria. Poult Sci 83(8): 1452-1455.

24. Berrang ME, Buhr RJ, Cason JA (2000) Campylobacter recovery from external and internal organs of commercial broiler carcass prior to scalding. Poult Sci 79: 286-290.

25. Firlieyanti AS, Connerton PL, Connerton IF (2006) Campylobacters and their bacteriophages from chicken liver: The prospect for phage biocontrol. Int J Food Microbiol 237:121-127.

26. Bartkowiak-Higgo AJ, Veary CM, Venter EH, Bosman A-M (2006) A pilot study on post-evisceration contamination of broiler carcasses and ready-to-sell livers and intestines (mala) with Campylobacter jejuni and Campylobacter coli in a high-throughput South African poultry abattoir. J S Afr Vet Assoc 77(3): 114-119.

27. Ewnetu D, Mihret A (2010) Prevalence and antimicrobial resistance of Campylobacter isolates from humans and chickens in Bahir Dar Ethiopia. Foodborne Pathog Dis 7(6): 667-670.

28. Abd El-Baky RM, Sakhy M, Gad GFM (2014) Antibiotic susceptibility pattern and genotyping of campylobacter species isolated from children suffering from gastroenteritis. Indian J Med Microbiol 32(3): 240-246.

29. Dabboussi F, Alam S, Mallat H, Hlais S, Hamze M (2012) Preliminary study on the prevalence of Campylobacter in childhood diarrhoea in north Lebanon. East Mediterranean Health Journal 18(12): 1225-1228.

30. Rao MR, Naficy AB, Savarino SJ, Abu-Elyazeed R, Wierzba TF, et al. (2001) Pathogenicity and convalescent excretion of Campylobacter in rural Egyptian children. Am J Epidemiol 154(2): 166-173.

31. Osbjer K, Tano E, Chhayheng L, Mac-Kwashie AO, Fernström LL, et al (2016) Detection of Campylobacter in human and animal field samples in Cambodia. APMIS 124(6): 508-515.

32. El-Gohary A (1998) Prospective studies on campylobacteriosis in human and animals in contact. Assiut Vet Med J 38: 192-208 
33. Adekunle OC, Coker AO, Kolawole DO (2009) Incidence, isolation and characterization of Campylobacter species in Osogbo. Biology Medicine 1(1): 24-27.

34. Pazzaglia G, Bourgeois AL, el Diwany K, Nour N, Badran N, et al. (1991) Campylobacter diarrhoea and an association of recent disease with asymptomatic shedding in Egyptian children. Epidemiol Infect 106(1): 77-82.

35. Blaser MJ, Wells JG, Feldman RA, Pollard RA, Allen JR (1983) Campylobacter enteritis in the United States. A multicenter study. Ann Intern Med 98(3): 360-365.

36. Karmali MA, Fleming PC (1997) Campylobacter enteritis in children. J Pediatr 94(4): 527-533.
37. Blaser MJ, Taylor DN, Echeverria $P(1986)$ Immune response to Campylobacter jejuni in a rural community in Thailand. J Infect Dis 153(2): 249-254.

38. Janssen R, Krogfelt KA, Cawthraw SA, van Pelt W, Wagenaar JA, et al. (2008) Host-pathogen interactions in Campylobacter infections: the host perspective. Clin Microbiol Rev 21(3): 505-518.

39. Grzybowska-Chlebowczyk U, Kalita B, Flak-Wancerz A, Jasielska M, Więcek S, et al. (2013) Clinical course of Campylobacter infections in children. Pediatr Pol 88(4): 329-334.

40.Zaman R (1992) Campylobacter enteritis in Saudi Arabia. Epidemiol Infect 108(1): 51-58.

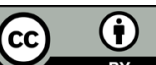

Creative Commons Attribution 4.0

International License

For possible submissions Click Here

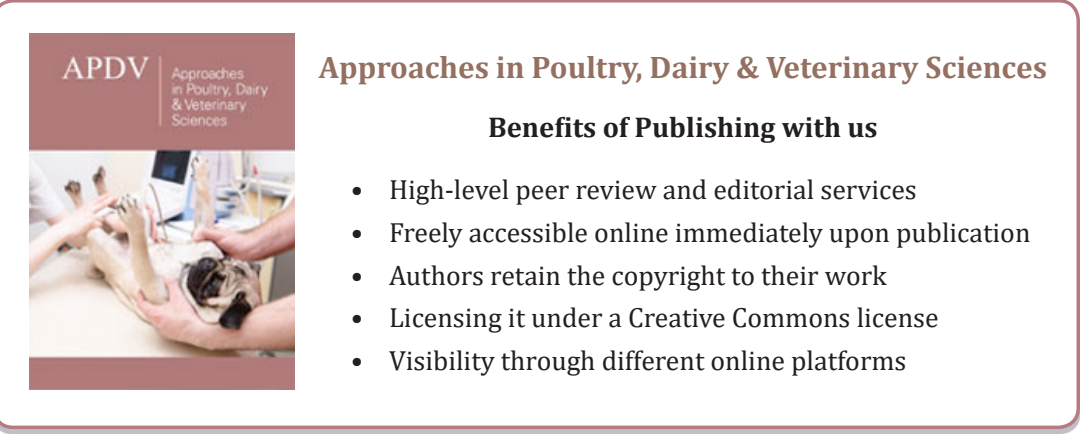

